\title{
Biology and Philosophy. Part I. The Paleolithic
}

\author{
Juan S. Gómez-Jeria
}

\begin{abstract}
An analysis of the Neanderthal Bruniquel cave is presented with an entirely new proposal of how the animal-human relationship was born. The Venus figurines and the European and Sulawesi cave paintings are briefly analyzed and explained in terms of a simultaneous qualitative change in the brain of some anatomically modern humans. Composite creatures are explained in terms of the new idea and without assuming an initial need of to consume psychoactive plants or mushrooms.
\end{abstract}

Index Terms - Bruniquel Cave, Evolution, Modern Homo sapiens, Neanderthal, Paleolithic.

\section{INTRODUCTION}

After reading the books of Erwin Schrödinger (Nature and the Greeks, [1]) and Eric Dodds (The Greeks and the Irrational, [2]) I began to write down some thoughts concerning the proper questions that should be posed to better understand the internal evolution (the results of the cephalization process of Teilhard de Chardin, see Man's place in nature: The human zoological group, ${ }^{[3]}$ ) of our ancestors and related species (or subspecies). My central interest was the analysis of the process of Myth creation and its alleged transition to the Logos of the first Greek natural philosophers (the pre-Socratics). After some years, I became convinced that I had something new and interesting to present about some pre-Socratics, a later Greek school of thought and Friedrich Nietzsche. But, happily or unhappily, I found Paul Feyerabend's Philosophy of Nature ${ }^{[4]}$. In this appealing and stimulating text, Feyerabend presents his own interpretation of Paleolithic knowledge that will not be discussed here, but motivated me to carry out a new analysis of this topic. In this part I will present some thoughts related to the Paleolithic period.

\section{The BRUniQuel CAVE}

The main use of time by our distant ancestors was for hunting, gathering food, mating, eating, sleeping, nursing and playing, like all primates. What kind of information or basic knowledge was necessary to survive at that time? They needed to know (i.e., to have an internal representation of some kind) the animals hunting humans for food or simply killing humans. They needed to know how to find the gathering place, if there was one, to rest, interact and/or sleep. They must possess enough information about how to reach places with constant water and/or supply of plants/fruits. The formation of large groups seems to have been produced by environmental pressures: the isolated individual would be

Juan S. Gómez-Jeria, Faculty of Sciences, University of Chile, Santiago, RM, Chile killed more easily (this selection mechanism also selected right-handed individuals later). For these primary activities there is no a need of any conscious knowledge about periodicities (for example, rhinos use trails to travel between feeding areas and salt-licks, but the unanswered question is who built the first trail). With the passing of time the archaic Homo sapiens sapiens and Homo sapiens Neanderthalensis acquired new knowledge, conscious or not: where the routes for specific migrating animals to hunt them were, the places and times where edible animals usually drank and/or ate, advanced ways to hunt (a conscious use of cliffs or dead ends for hunting). A warning. When I use the term conscious the reader should not think that our ancestors and related members of the genus Homo had the same way to be conscious as us. Clearly speaking, we know nothing and we will not know anything about this subject. And this is the weakest side of many interpretations of paleoanthropological findings. I have read many papers and some books filled with words like "if we accept that", "it could be that" "it seems that", etc., followed by long paragraphs filled with statements that seem to be scientific. Let us remember that a scientific hypothesis (a proposition) must be true or false, and that there must be a way to determine the truth or falsehood of it. If we are not able to carry out this procedure, we are condemned to merely tell interesting stories. And here Occam's razor does not work. Here goes an example.

Let us consider the recent archeological findings at 336 meters from the entrance of the Bruniquel Cave in southwestern France [5]. Anthropogenic annular constructions made of broken stalagmites were found that are dated to about 176.4 thousand years before present.

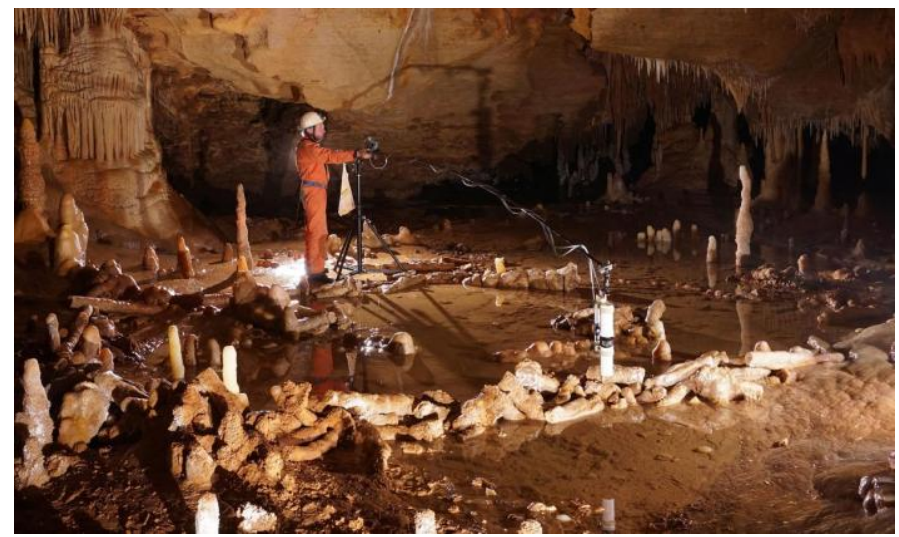

Figure 1. The structures inside Bruniquel Cave. Credit: Etienne Fabre.

No footprints or marks on the walls were observed. No tools inside the cave. Traces of fire exist on all structures. The date is within the marine isotope stage 6 (MIS 6) and at that moment and place the climate was quite warm and humid 
despite glacial conditions.

There is no doubt that these structures were built by a group of two or more early Neanderthals (there were no Homo sapiens sapiens in that place at that time). From the analysis of the Site of Payre we may conjecture that the Neanderthals of the Bruniquel Cave, in addition to hunt large terrestrial herbivores, also exploited starchy plants, birds and fish ${ }^{[6-8]}$. What we do not know is when, by trial and error or by a simple mistake, they discovered plants with psychoactive effects if they did ${ }^{[9-12]}$. The abovementioned structures show that cooperation among individuals was doing well at that time. The authors ask about the function of these structures "at such a great distance from the cave entrance". Given that the Neanderthal group had time to build the structures, we may assume that they entered the cave one or more times willingly and in no hurry. Assuming that at that time the artificial structures were located 336 meters from the real cave entrance the question is why the Neanderthals went so far in. At his moment, a long list of possibilities can be built. But note that, given that we know nothing about the Neanderthal's mind, this list may miss some "Neanderthal possibilities" that we cannot imagine. Therefore, what follows is only a story I wrote. I took a long time to build a decision tree with many possibilities to see if a realistic answer could be suggested (realistic is not here a synonym of true). The following is the result of that work. We may first think that they were avoiding predators, but the finding that bears were present (perhaps Ursus deninger or Ursus spelaeus) precluded this idea for the moment. The hypothesis of a kind of usual dining place could be dismissed on the same basis and also because the absence of large quantities of bone remnants is symptomatic of that. Jaubert et al. suggest some kind of "symbolic" or "ritual" behavior, a suggestion that will be commented on below. My story of what could have happened is this one. A Neanderthal entered a cave for the first time and walked until he reached a place where external light could not be seen (the case of this cave). Why did he enter? Because, like me and you and all primates, he was curious. To find his way he employed a primitive torch, such as a burning piece of wood. He could face two possibilities. In the first, his torch burned out and he was surrounded by total darkness, pushing him out of the cave. Next time he returned with more torches and maybe with more curious Neanderthals. What did he see at the very place were the circular structures would be built later? Before providing a tentative answer, let me remind you of Ezekiel's vision (in the Bible's Book of Ezekiel). It seems that Ezekiel saw something. What? We will never know. But he saw something never seen before by him and he did the only thing a human can do. He described what he saw in terms of known objects and situations stored in his memory. This is the only thing he could do and it is the only thing that any one of us will do in a similar situation.

Inside the cave the Neanderthal saw an illuminated 3D volume with fluctuating shadows on the walls, on the rocks, on the stalagmites, on the stalactites and on the bodies of his companions. Perhaps he noticed that some light/dark combinations resembled animals he knew and/or perhaps that some of his companions sometimes also looked like known friendly or unfriendly animals. Note, I repeat, that any relationship he could find in the interplay of light/darkness would be always interpreted in terms of what he knew (with anything he had stored in his memory). If this activity motivated him, and I think that this is the case, he would return and build a place to stay in calm and perhaps to sit and watch. He "thought" the effect of the light on the structures was better if the torch was placed on the built structures and not on the floor. This could be why the fireplaces are located on the structures and not on the floor. If more Neanderthals experienced these light/darkness interplays it is more than probable that they also observed this (apparent) resemblance of some human faces to known animals. It is certain that these animal/people associations could also be observed when Neanderthals were outside the cave around a wood fire, but not with such intensity or durability. Perhaps this is the first stage of the animal/person association and the origin of more elaborate ideas, such as the totem. And, if all this is true, there is no reason to forbid them from transmitting in their own way this knowledge to others or simply bringing them inside the cave to watch. Surely the same phenomena occurred also with Homo sapiens sapiens in other places and times, being probably reinforced by the use of psychoactive substances (see below). After these speculative thoughts I cannot add more about this particular group of Neanderthals (for Neanderthals, see also ${ }^{[13-18]}$ ). Maybe they became extinct or maybe their descendants mixed with the first Homo sapiens sapiens arriving in Europe.

What about the Neanderthal mind? I think that the following statement is true: we know nothing and we will remain forever ignorant about this subject. Stating that the circular structures "represent some kind of symbolic or ritual behavior" is only to shoot in the dark. Discarding the suggestions of the usual intellectual offenders who surely will state that these structures were an alien camping site, the list of possibilities is very short but we have no way to select any of them to associate them with "symbolic" or "ritual" behavior. Roebroeks and Soressi made a wise declaration regarding this topic: Translating archeological finds into statements about complex cognition and use of symbols involves a series of inferential steps, only some of which can be supported by solid evidence, given the elusive character of symbols from past societies ${ }^{[15]}$. Shells, feathers, claws, use of chemicals to dye or paint, subsistence strategies, social organization, etc., can be classified only as belonging to a Neanderthal catalogue of behaviors and products ${ }^{[19-25]}$. The Neanderthal burials found are dated to times when they coexisted with modern humans. We do not know if Neanderthals invented or copied this behavior and we do not know if their burials carry any symbolism (i.e., if they were funerals).

In pages 366 to 391 of his book, Mellars presents his ideas about the Neanderthal mind ${ }^{[26]}$. He begins by presenting the following two basic assumptions: that there were no significant contrasts between the mental capacities of Neanderthal and modern humans (impossible to prove this), and that there were significant differences in the mental or cognitive capacities of Neanderthal populations (p. 366). Regarding the last assumption, Crabtree opened an 
interesting exchange of opinions when he stated that "I would wager that if an average citizen from Athens of $1000 \mathrm{BC}$ were to appear suddenly among us, he or she would be among the brightest and most intellectually alive of our colleagues and companions, with a good memory, a broad range of ideas, and a clear-sighted view of important issues" [27]. Despite the about 2,500 years separating us from them, the average citizen of Athens surely was very different from the average inhabitant of today's cities due to the current uncontrolled population growth. Given the extension of the known boundaries of Neanderthal occupation in Eurasia it is possible that groups separated by large distances fulfill Mellars' second assumption and developed different mental and/or cognitive capacities, but there is no proof of this. Well, there is a third hypothesis stating that the mental capacities of Neanderthals and modern humans are entirely different. Another source of trouble is that Mellars does not clarify what he means by "modern humans": the ones dated 200,000 years ago, 120,000 years ago, 40,000 years ago, or today's humans? [26]. The catalogue of Neanderthals' known behaviors and their products will probably be enlarged in the future but in no way will it be useful to decode their minds. Let me offer a quite radical example. In the far future archeologists from another planet excavated in a completely destroyed and empty Earth and found the two photos shown in Fig. 2.

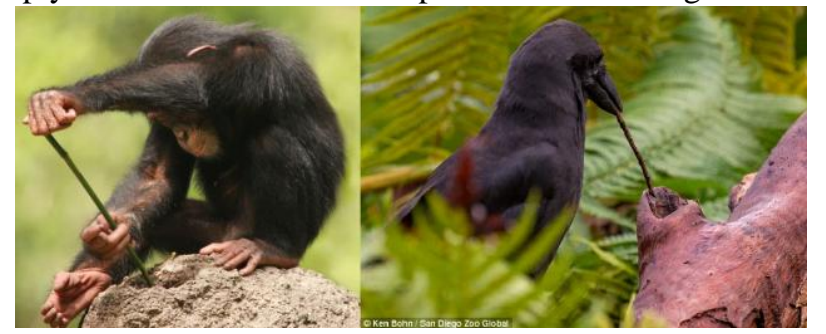

Figure 2. Photos found in archeological excavations made by alien archeologists in a dead Earth (Credits: left, Adam Jones, right, Ken Bohn San Diego Zoo).

At the corresponding Planetary Archeology Symposium the experts of that time interpret the photos stating that both unknown species seem to have the same behavior and therefore a similar mind. Both photos strongly suggest that both species communicate, that the flying species on the right probably learnt the behavior from the terrestrial one by watching it from the air, and so on. A single archeologist claims that more research is absolutely necessary to find solid evidence to support any of these suggestions, but the habitual Peacocks disregard his claim (yes, I am ironizing). Well, the situation is almost exactly the same regarding Neanderthals. We need more findings to see if some day any progress in this area can be achieved. But there are two statements about the Bruniquel Neanderthals and probably about all or almost all members of this subspecies that I can hold confidently. The first one states that some of them were endowed with a better genetic heritage allowing them to behave in that way. The second is a corollary of the first: Bruniquel's structures are the initial work of some individuals and not of the whole group. Findings of non-utilitarian objects such as the ones at Kaprina (in actual Croatia, 130 kyr, ${ }^{[23]}$ ), Gorham's Cave (Gibraltar, $39 \mathrm{kyr},{ }^{[28]}$ ) and other places ${ }^{[29]}$ show that, sometimes, a new intellectual spark was being born and was trying to propagate (this is a poetic license).

\section{THe UpPer Pleistocene (C. 129 KYR - C. 12 KYR).}

Modern humans arrived in Europe about $45 \mathrm{kyr}$ ago. Recent research of the genetic history of Ice Age Europe can be summarized as follows (I directly copied some of the conclusions of Ref. ${ }^{[30]}$. That paper is not only good but also beautiful):

1. First, at least some of the initial modern humans to appear in Eurasia, exemplified by Ust'-Ishim and Oase1, failed to contribute appreciably to the current European gene pool. Only from around 37,000 years ago do all the European individuals analyzed share ancestry with present-day Europeans.

2. From the time of Kostenki14 about 37,000 years ago until the time of the Villabruna Cluster about 14,000 years ago, all individuals seem to derive from a single ancestral population with no evidence of substantial genetic influx from elsewhere. It is interesting that during this time, the Mal'ta Cluster is not represented in any of the individuals we sampled from Europe. Thus, while individuals assigned to the Gravettian cultural complex in Europe are associated with the Věstonice Cluster, there is no genetic connection between them and the Mal'tal individual in Siberia, despite the fact that Venus figurines are associated with both. This suggests that if this similarity is not a coincidence, it reflects diffusion of ideas rather than movements of people.

3. Third, we find that GoyetQ116-1 derives from a different deep branch of the European founder population than the Věstonice Cluster which became predominant in many places in Europe between 34,000 and 26,000 years ago including at Goyet. GoyetQ116-1 is chronologically associated with the Aurignacian cultural complex. Thus, the subsequent spread of the Věstonice Cluster shows that the diffusion of the Gravettian cultural complex was mediated at least in part by population movements.

4. Fourth, the population represented by GoyetQ116-1 did not disappear, as its descendants became widespread again after 19,000 years ago in the El Mirón Cluster when we detect them in Iberia. The El Mirón Cluster is associated with the Magdalenian culture and may represent a post-Glacial Maximum expansion from southwestern European refuges.

The authors also stated that "over this time, the proportion of Neanderthal DNA decreased from 3-6\% to around 2\%, consistent with natural selection against Neanderthal variants in modern humans" [30]. But there is at least one exception. The DNA analysis of a 37-42 kyr-old modern human from Peştera cu Oase (in present day Romania), shows that the order of $6-9 \%$ of the genome of the Oase individual is

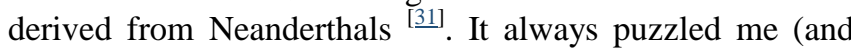
surely many others) why there are no Neanderthals with human DNA ${ }^{[14]}$. A recent work shows that this kind of mixture is found in the Altai Mountains (Siberia) ${ }^{[17]}$. The conclusion of the authors is that "the ancestors of Neanderthals from the Altai Mountains and early modern humans met and interbred, possibly in the Near East, many thousands of years earlier than previously thought $[100,000$ years]". This is supported by the recent finding of the Daoxian teeth that are the earliest evidence of definitely modern humans in southern China at least $80 \mathrm{kyr}$ ago ${ }^{[32]}$. Before returning to our discussion, I will add that Asian and Oceanian human paleontology are still today a mystery 
because almost no research has been carried out $[\underline{13}, \underline{33}]$. Several kinds of admixtures (hybrids) probably occurred there because of Asian geography, extension, hominids arriving there more than one million years ago and role of Asia as a stepping stone to move toward Oceania $\underline{[34}, \underline{35]}$.

\section{THE VENUS FIGURINES.}

We must not forget that men in Paleolithic period were nomads. They used to move from one place to another following the accessibility of natural resources for survival. They survived on hunting animals and birds, fishing and collecting fruits, nuts and maybe some plants and mushrooms (hunter-gatherers). We do not know when they associated too much inbreeding with the disastrous genetic disorders and other consequences that may arise from incestuous sexual relationships and consanguinity. As no human remains with notorious genetic alterations have been found, we may suppose that they died very young, were left to die, were killed or simply they could not adapt themselves to the environmental conditions. No doubt that the constant movement in search of resources allowed the interaction with other groups and the exchange of genetic material. Now, let us examine the Venus figurines in Fig. 3.

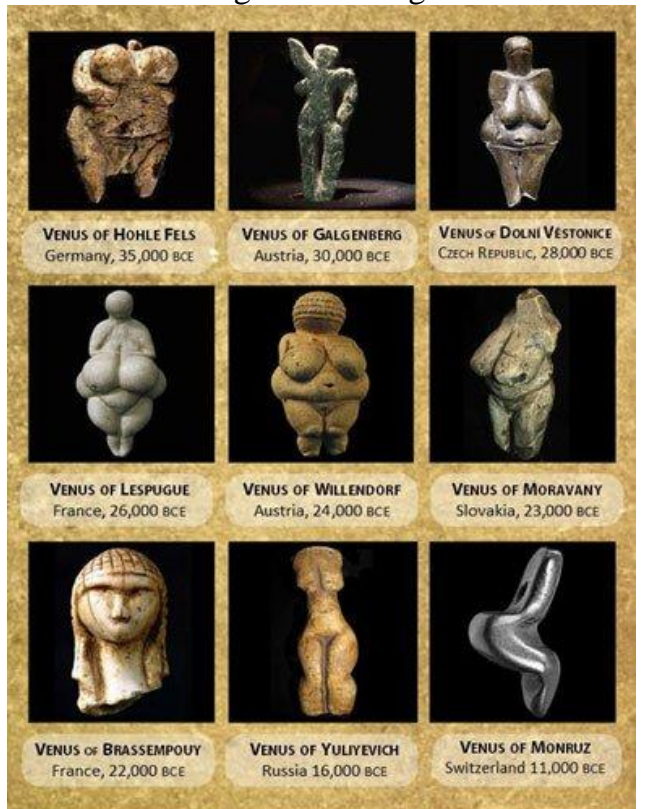

Figure 3. Some examples of Venus figurines (Credit: April Holloway).

The main problem on this topic is that we do not know if we have found the oldest one (i.e., the first figurine) and also we do not know the real geographical extension of the area of fabrication (Fig. 4).

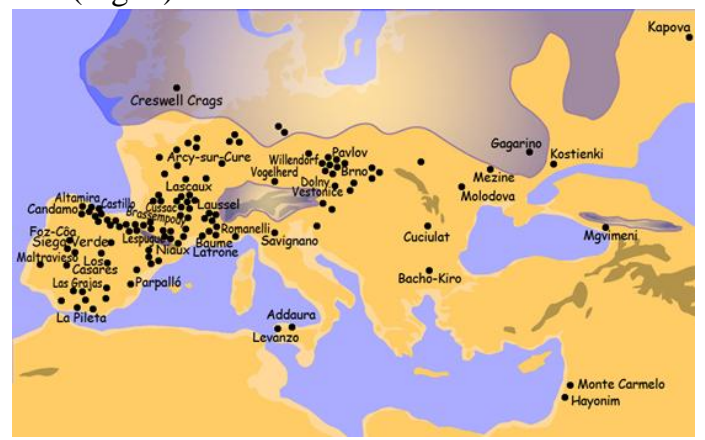

Figure 4. Distribution of known Venus figurines (from https://upperpalaeolithicart.wordpress.com/2014/04/10/Venu

\section{s-figurines/)}

The abovementioned conclusion number 2 suggests that if the similarity among these figurines is not a coincidence, it reflects dissemination of ideas rather than movements of people. Even if we analyze the whole set of today's figurines we cannot even suggest a point of origin. The ordering by date is not helpful because of the unsolved problem of where the oldest figurine was made and if we have discovered it. The ordering by manufacturing quality is impossible because we do not know what Venus figurines were totally finished (we may guess) and, in the case of what could be considered a bad quality figurine, we do not know if the artist was a bad one. But there is a statement we can hold (almost) confidently: all, or almost all men living in Eurasia that made these figurines seemed to speak a common language. This is indirectly supported by an elegant study showing the existence of a set of highly conserved words among seven language families of Eurasia postulated to form a linguistic superfamily that evolved from a common ancestor around 15,000 years ago ${ }^{[36]}$. Seven of the nine figurines shown in Fig. 3 are very much older than this date, and their manufacture technique could have originated in a common place and expanded geographically through people traveling and carrying the know-how. Of course, there is the possibility of the existence of two or more simultaneous manufacturing places but always we are dealing with one or two individuals who had first acquired the biological ability to carry out this work and to teach others. The association of pregnancy with the woman's body changes is easily understood when a link can be made with the body change in mammalian females of other species living around. Surely Homo sapiens living in these times killed many times pregnant female animals to eat them and found the fetus inside and also surely they saw females of other species giving birth. If the Venus figurines are representations of pregnancy (fertility) this could explain its wide geographic distribution in Eurasia. What we do not know if this association was made simultaneously in two or more geographically separated places and how this association was transmitted by the traveling groups but the Venus figurines show what it seems to be a common idea about female fertility and nothing more. But nobody will deny that these figurines were the work of an initially small group of gifted individuals and that they were later copied by those people having the skill to do this work.

When the link of coitus with pregnancy was firstly noted? Remember that the time lapse between coitus and pregnancy avoids a direct connection. But it seems that this relationship was noted during the Paleolithic and no doubt it is associated with the appearance of phallus figurines. A good example is the sculpted and polished phallus $(20 \mathrm{~cm}$ long, $3 \mathrm{~cm}$ wide stone object), dated to be about $28 \mathrm{kyr}$ old, found in the Hohle Fels Cave in the Swabian Jura (actual Germany, see Fig. 5).

For those ones proposing phallic cults and/or dildos (yes! I read this suggestion somewhere) at that time, I will cite a phrase I read (I do not remember where): these interpretations say a lot about the mind of the proposers (their own Rorschach-like test) than about reality. Angulo et al. have published three papers dealing with Paleolithic phalluses [37-39]. I will center my comments on only two examples, 
shown in Figs. 6 and 7.

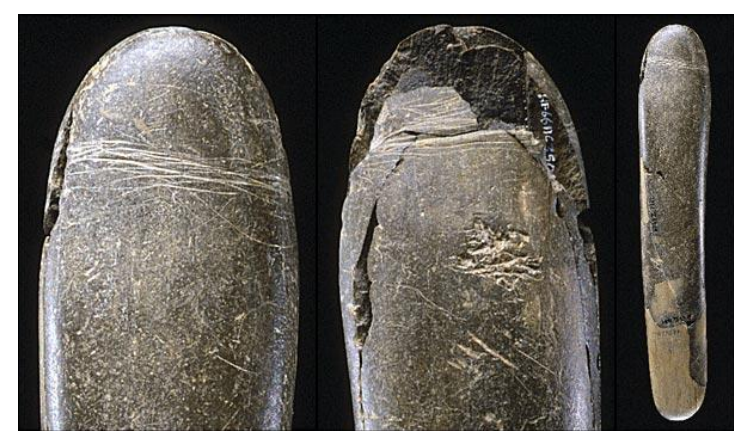

Figure 5. Stone phallus from the Hohle Fels Cave (28 kyr old, Credit: J. Liptak).
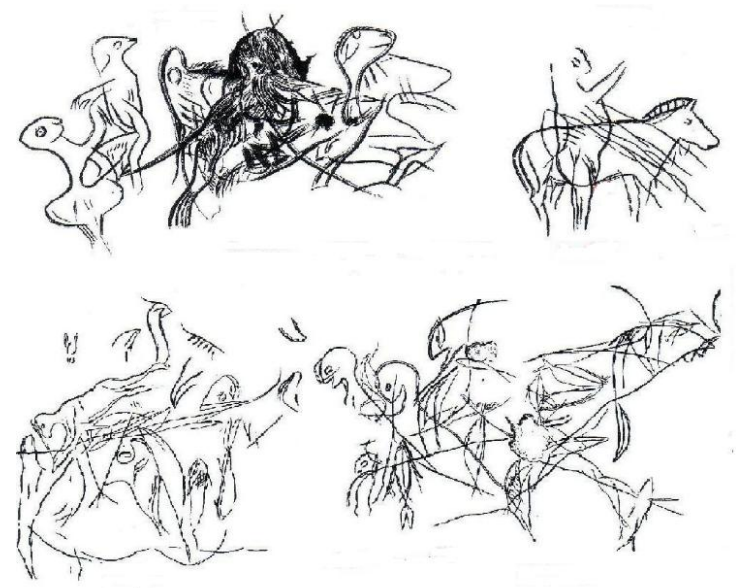

Figure 6. Engravings in the Cueva de los Casares.

Figure 6 is found in Cueva de los Casares (actual Portugal). The upper left figure is interpreted by Angulo et al. as representing copulation. It could be that. As far as I know these specific figures have not been clearly dated. The remaining engravings are very complex and have been interpreted au goût du consommateur. Curiously these engravings, compared with the magnificent cave paintings, look like graffiti.

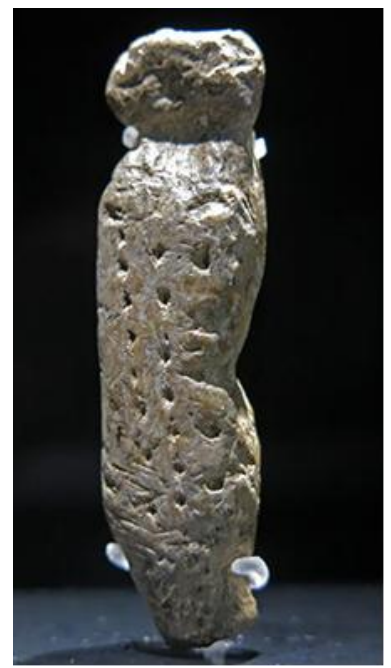

Figure 7. Ivory statuette from the Vogelherd Cave (Photo: Don Hitchcock, 2015).

Figure 7 is an ivory statuette from Vogelherd Cave (length $69 \mathrm{~mm}$, depth $10.5 \mathrm{~mm}$, width $19 \mathrm{~mm}$ ). Angulo et al. interpreted this statuette as a phallic statuette. Another possible interpretation is that, as this figurine has some similarities with that of Trou-Magrite (actual Belgium), it could be a Venus statuette. Nevertheless, this figurine is not likely to be properly considered feminine. We wait for more experts' opinions.

\section{CAVE PAINTINGS.}

Some decades ago, Europe seemed to be the only place having Paleolithic cave paintings. Recently, it was demonstrated that humans were producing rock art by about $40 \mathrm{kyr}$ ago at opposite ends of the Paleolithic Eurasian world [40] (circa $40 \mathrm{kyr}$ in both places). There are two main hypotheses to explain this fact. First: Some Homo sapiens of Europe and some Homo sapiens of Sulawesi developed this remarkable ability almost simultaneously, suggesting that this skill has a common genetic basis. A possible corollary is that the common ancestors of both populations had a brain structure ready for change in that direction. Second: There is a common center located somewhere between these two points. The only way to decide what hypothesis is true is more research in Asia (let us remember that the sea level increased by about $120 \mathrm{~m}$ at the end of the last glaciation). It seems clear that this ability greatly expanded at least in Europe (this is a statement based only on the fact that more caves are known at that place). We have seen the marvelous paintings in European and Sulawesi caves. A question for meditation. Are some paintings or drawings created by "bad" artists? Figure 5 shows some drawings from the Grotte des Trois-Frères.

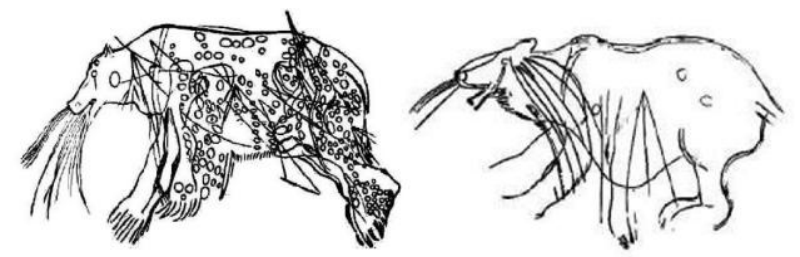

Figure 5. These drawings seem to be a representation of the use of bolas (Grotte des Trois-Frères, France, 13 kyr).

They represent a possible use of bolas to hunt. Both animals seem to lose blood from their noses and/or mouths. They look quite primitive compared with other paintings and drawings. We could think that they were made by beginners. But possibilities such as an urgent need to express the excitement of a successful hunt or of participating in such activity for the first time cannot be ruled out (the right side figure may also represent the use of spears). Figure 6 shows a possible representation of a volcanic eruption.

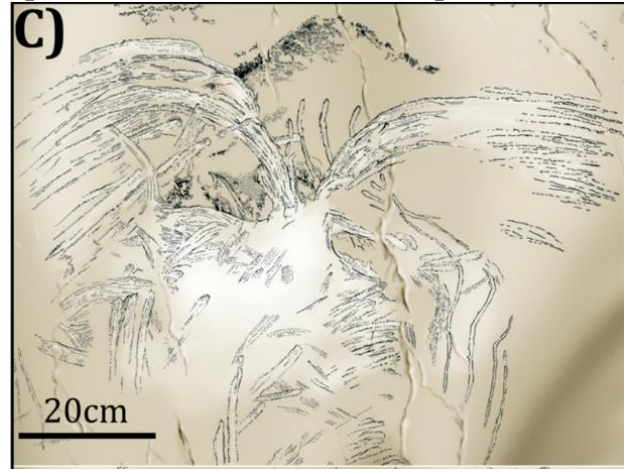

Figure 6. Drawing of a possible volcanic eruption 
(Chauvet-Pont d'Arc cave, Ardèche, France, 36 kyr, from Ref. $\left.{ }^{[41]}\right)$.

The representation seems to be well made considering that the "cartoonist" was probably watching this phenomenon. Questions such as if he was afraid could receive a simultaneous yes and no answer. Yes because of the fear of the eruption itself and no because volcanic activity was common in this area (between 29 and $35 \mathrm{kyr},{ }^{[41]}$ ). Now, if he was witnessing his first volcanic eruption the answer should be only yes despite the fact that he could have heard tales about earlier ones.

\section{ON THE COMPOSITE CREATURES.}

These representations evidence both human and animal characteristics. We shall not confuse these creatures with cases of therianthropy because there is no basis for doing this. Neither shall we refer to them as a departure from normality (I read this low level comment somewhere). Figures 7 to 9 show some of them.

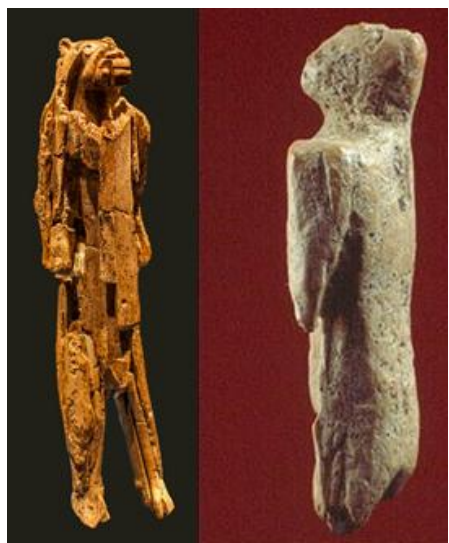

Figure 7. From left to right: the lion-man of the Hohlenstein-Stadel (Lone Valley, actual Germany, 35-40 kyr), the lion-man of Hohle Fels (Swabian Jura, actual Germany, 30-32 kyr).

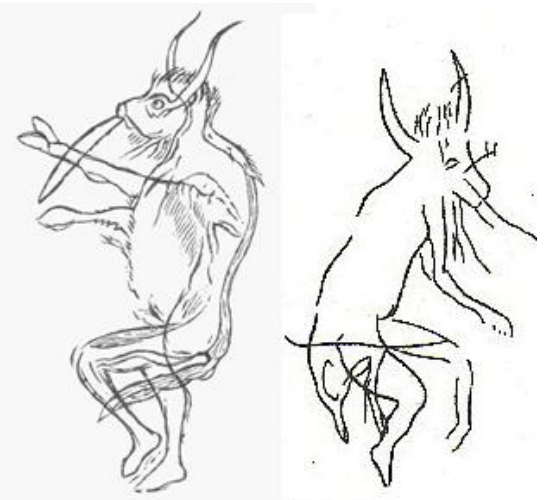

Figure 8. From left to right: Bison-headed man (Le Gabillou Cave, actual France, about 15 kyr). Man-as-ox (Le Gabillou Cave, actual France, about 15 kyr).

The idea that the Homo sapiens brain suffered a sudden qualitative change about $40 \mathrm{kyr}$ ago looks convincing on the basis of what seems to be an abrupt explosion of new products (Venus figurines, cave paintings, etc.). I think that it is at this moment when we can properly speak of modern Homo sapiens (i.e., the anatomically modern humans that appeared about $200 \mathrm{kyr}$ plus the brain change). And it seems that this change occurred at least in Eurasia and Oceania in a sufficient number of individuals to propagate up to our days.
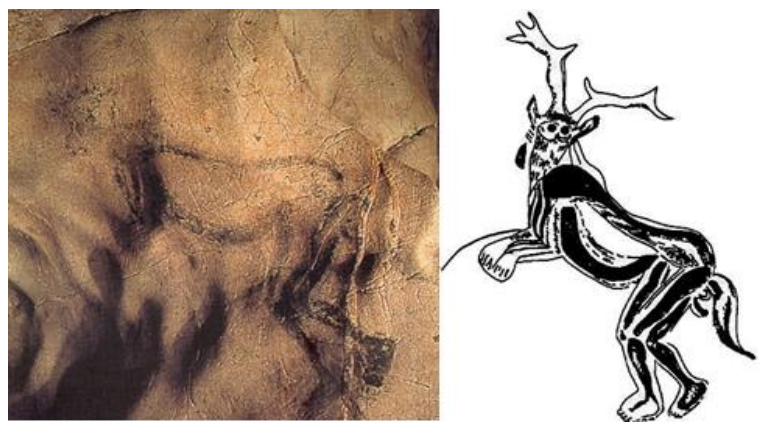

Figure 9. Left: The Sorcerer (Cave of the Trois-Frères, actual France, about 15 kyr). Right: Sketch of Breuil's drawing.

The notion of Figs. 7-9 as a departure from normality seems to me as ridiculous as the one proposing that the Neanderthals disappeared because our ancestors arrived with dogs that killed them. Another idea is that the sudden appearance of artistic forms is due the use of hallucinogenic plants. The actual disaster that the use of hallucinogenic drugs is causing daily in the world militates against this idea (not all brains and minds are equal). Also, the simultaneous appearance of cave paintings in Europe and Sulawesi would imply that in these places people began to use hallucinogens at the same time, an assertion that is highly doubtful. I think that all readers will agree that our distant ancestors (Homo habilis, Homo erectus, etc.) discovered by trial and error what kind of vegetable materials could be eaten. If some of them ate the wrong vegetable they died. But the association of "eating this vegetable" with "death" could only be reached after a long time and much observation. Table 1 shows some plants and mushrooms with psychoactive properties available in Eurasia (I am not sure if all them were available at that time).

Table 1. Some plants and mushrooms available in Eurasia.

\begin{tabular}{|c|c|c|}
\hline Common name & Genus / Species & Native to \\
\hline Amanita - Fly agaric & Amanita muscaria & \begin{tabular}{|l} 
Siberia \\
\end{tabular} \\
\hline \begin{tabular}{c|} 
Belladonna - \\
Nightshade \\
\end{tabular} & Atropa belladonna & $\begin{array}{c}\text { Europe \& Middle } \\
\text { East } \\
\end{array}$ \\
\hline Cannabis - Hemp & Cannabis sativa & $\begin{array}{c}\text { India \& Middle } \\
\text { East }\end{array}$ \\
\hline $\begin{array}{c}\text { Datura - Thorn } \\
\text { apples }\end{array}$ & Datura spp. & India \\
\hline Ephedra - Ma huang & Ephedra sinica & China \\
\hline Ergot & Claviceps purpurea & Europe \\
\hline Elephant creeper & Argyreia nervosa & Indian subcontinent \\
\hline Henbane & Hyoscyamus niger & $\begin{array}{c}\text { Europe \& Middle } \\
\text { East } \\
\end{array}$ \\
\hline Intoxicating Mint & Lagochilus inebriens & Central Asia \\
\hline Lotus - Water lily & $\begin{array}{c}\text { Nymphaea spp.; Nelumbo } \\
\text { spp. }\end{array}$ & Egypt \\
\hline Mucuna pruriens & Mucuna pruriens & Asia \\
\hline Mandrake & Mandragora officinarum & $\begin{array}{c}\text { Europe \& Middle } \\
\text { East } \\
\end{array}$ \\
\hline Poppies & Papaver spp. & Persia \& Asia \\
\hline Sakae Naa & $\begin{array}{c}\text { Combretum } \\
\text { quadrangulare }\end{array}$ & Southeast Asia \\
\hline Syrian Rue & Peganum harmala & Persia \& India \\
\hline Wild Lettuce & Lactuca virosa & Europe \\
\hline Wormwood & Artemisia absinthium & Europe \\
\hline
\end{tabular}


Let us return now to my abovementioned suggestion that the origin of the man-animal relationhip was simply born inside an illuminated cave and transmitted from one generation to another. The cases of the Homo sapiens living in the Near East or the first Homo sapiens arriving in Europe is similar: many of them lived in caves and surely observed the same light/dark interplay. And, at some moment we probably never know, one or more of them began to ingest the right hallucinogenic dose of, for example, Amanita muscaria. And this probably happened throughout Eurasia and not at a specific geographic point. Therefore, for Figs. 7 to 9 I offer the following explanation. They are simple representations of the man-animal association observed inside caves, with or without the use of hallucinogens. Figure 9 perhaps (and only perhaps) might represent a real human dressed with the external symbols of what he saw in his mind. Let us remember that in later ancient American cultures, whose descendants use hallucinogens even today, the man-animal relationships always include an animal living in the place and not a Plesiosaur or an Archaeopteryx.

In summary I present the idea that, even after what seems to be a qualitative change of the brain of the anatomically modern humans that happened about $50 \mathrm{kyr}$, one or more genetically gifted individuals were always discovering new ways to knowledge, new ways of adapting to the environment and of progressing. Poetically speaking, the rest of Homo sapiens are like the mud or humus on which evolution was continually working at that time (and today) to produce more adapted and superior individuals. In the next paper we shall show how this phenomenon is consciously and openly exposed by some Greek philosophers.

\section{REFERENCES}

[1] Schrödinger, E. Nature and the Greeks. Cambridge University Press: Cambridge England, 1954.

[2] Dodds, E. R. The Greeks and the irrational. 1st Beacon paperback ed.; Beacon Press: Boston, 1957.

[3] Teilhard de Chardin, P. Man's place in nature: the human zoological group. Collins: London, 1966; $\mathrm{p} 4$.

[4] Feyerabend, P. K. Philosophy of Nature. John Wiley \& Sons: 2016.

[5] Jaubert, J.; Verheyden, S.; Genty, D.; Soulier, M., et al. Early Neanderthal constructions deep in Bruniquel Cave in southwestern France. Nature 2016, 534, 111-114.

[6] Esteban, I.; Albert, R. M.; Eixea, A.; Zilhão, J.; Villaverde, V. Neanderthal use of plants and past vegetation reconstruction at the Middle Paleolithic site of Abrigo de la Quebrada (Chelva, Valencia, Spain). Archaeological and Anthropological Sciences 2015, Springer Berlin Heidelberg, 1-14.

[7] Hardy, B. L.; Moncel, M.-H. Neanderthal Use of Fish, Mammals, Birds, Starchy Plants and Wood 125-250,000 Years Ago. PLOS ONE 2011, 6, e23768.

[8] Richards, M. P.; Trinkaus, E. Isotopic evidence for the diets of European Neanderthals and early modern humans. Proceedings of the National Academy of Sciences 2009, 106, 16034-16039.

[9] Solecki, R. S. Shanidar IV, a Neanderthal Flower Burial in Northern Iraq. Science 1975, 190, 880.

[10] Lietava, J. Medicinal plants in a Middle Paleolithic grave Shanidar IV? Journal of Ethnopharmacology 1992, 35, 263-266.

[11] Guerra-Doce, E. Psychoactive Substances in Prehistoric Times: Examining the Archaeological Evidence. Time and Mind 2015, 8, 91-112.

[12] Sommer, J. D. The Shanidar IV 'Flower Burial': a Re-evaluation of Neanderthal Burial Ritual. Cambridge Archaeological Journal 1999, 9, 127-129.

[13] Wall, J. D.; Yoshihara Caldeira Brandt, D. Archaic admixture in human history. Current Opinion in Genetics \& Development 2016, 41, 93-97.

[14] Varki, A. Why are there no persisting hybrids of humans with Denisovans, Neanderthals, or anyone else? Proceedings of the National Academy of Sciences 2016, 113, E2354.
[15] Roebroeks, W.; Soressi, M. Neandertals revised. Proceedings of the National Academy of Sciences 2016, 113, 6372-6379.

[16] Mounier, A.; Mirazón Lahr, M. Virtual ancestor reconstruction: Revealing the ancestor of modern humans and Neandertals. Journal of Human Evolution 2016, 91, 57-72.

[17] Kuhlwilm, M.; Gronau, I.; Hubisz, M. J.; de Filippo, C., et al. Ancient gene flow from early modern humans into Eastern Neanderthals. Nature 2016, 530, 429-433.

[18] Benito, B. M.; Svenning, J.-C.; Kellberg-Nielsen, T.; Riede, F., et al. The ecological niche and distribution of Neanderthals during the Last Interglacial. Journal of Biogeography 2016, n/a-n/a.

[19] Finlayson, C.; Brown, K.; Blasco, R.; Rosell, J., et al. Birds of a Feather: Neanderthal Exploitation of Raptors and Corvids. PLOS ONE 2012, 7, e45927.

[20] Heyes, P. J.; Anastasakis, K.; de Jong, W.; van Hoesel, A., et al. Selection and Use of Manganese Dioxide by Neanderthals. Scientific Reports 2016, 6, 22159.

[21] Peresani, M.; Fiore, I.; Gala, M.; Romandini, M.; Tagliacozzo, A. Late Neandertals and the intentional removal of feathers as evidenced from bird bone taphonomy at Fumane Cave 44 ky B.P., Italy. Proceedings of the National Academy of Sciences 2011, 108, 3888-3893.

[22] Peresani, M.; Vanhaeren, M.; Quaggiotto, E.; Queffelec, A.; d'Errico, F. An Ochered Fossil Marine Shell from the Mousterian of Fumane Cave, Italy. PLOS ONE 2013, 8, e68572.

[23] Radovčić, D.; Sršen, A. O.; Radovčić, J.; Frayer, D. W. Evidence for Neandertal Jewelry: Modified White-Tailed Eagle Claws at Krapina. PLOS ONE 2015, 10, e0119802.

[24] Roebroeks, W.; Sier, M. J.; Nielsen, T. K.; De Loecker, D., et al. Use of red ochre by early Neandertals. Proceedings of the National Academy of Sciences 2012, 109, 1889-1894.

[25] Zilhão, J.; Angelucci, D. E.; Badal-García, E.; d'Errico, F., et al. Symbolic use of marine shells and mineral pigments by Iberian Neandertals. Proceedings of the National Academy of Sciences 2010, 107, 1023-1028.

[26] Mellars, P. The Neanderthal legacy: an archaeological perspective from Western Europe. Princeton University Press: Princeton, N.J., 1996; p xix, $471 \mathrm{p}$

[27] Crabtree, G. R. Our fragile intellect. Part I. Trends in Genetics 2013, 29, 1-3.

[28] Rodríguez-Vidal, J.; d'Errico, F.; Pacheco, F. G.; Blasco, R., et al. A rock engraving made by Neanderthals in Gibraltar. Proceedings of the National Academy of Sciences 2014, 111, 13301-13306.

[29] Moncel, M. H.; Chiotti, L.; Gaillard, C.; Onoratini, G.; Pleurdeau, D. Non-utilitarian lithic objects from the European Paleolithic. Archaeology, Ethnology and Anthropology of Eurasia 2012, 40, 24-40.

[30] Fu, Q.; Posth, C.; Hajdinjak, M.; Petr, M., et al. The genetic history of Ice Age Europe. Nature 2016, 534, 200-205.

[31] Fu, Q.; Hajdinjak, M.; Moldovan, O. T.; Constantin, S., et al. An early modern human from Romania with a recent Neanderthal ancestor Nature 2015, 524, 216-219.

[32] Liu, W.; Martinon-Torres, M.; Cai, Y.-j.; Xing, S., et al. The earliest unequivocally modern humans in southern China. Nature 2015, 526 , 696-699.

[33] Qiu, J. The forgotten continent. Nature 2016, 535, 218-220.

[34] Brown, P.; Sutikna, T.; Morwood, M. J.; Soejono, R. P., et al. A new small-bodied hominin from the Late Pleistocene of Flores, Indonesia. Nature 2004, 431, 1055-1061.

[35] van den Bergh, G. D.; Kaifu, Y.; Kurniawan, I.; Kono, R. T., et al Homo floresiensis-like fossils from the early Middle Pleistocene of Flores. Nature 2016, 534, 245-248.

[36] Pagel, M.; Atkinson, Q. D.; S. Calude, A.; Meade, A. Ultraconserved words point to deep language ancestry across Eurasia. Proceedings of the National Academy of Sciences 2013, 110, 8471-8476.

[37] Angulo Cuesta, J.; García Díez, M. Diversidad y sentido de las representaciones masculinas fálicas paleolíticas de Europa occidental. Actas Urológicas Españolas 2006, 30, 254-267.

[38] Angulo, J. C.; García-Díez, M. Male Genital Representation in Paleolithic Art: Erection and Circumcision before History. Urology 2009, 74, 10-14.

[39] Angulo, J. C.; García-Díez, M.; Martínez, M. Phallic Decoration in Paleolithic Art: Genital Scarification, Piercing and Tattoos. The Journal of Urology 2011, 186, 2498-2503.

[40] Aubert, M.; Brumm, A.; Ramli, M.; Sutikna, T., et al. Pleistocene cave art from Sulawesi, Indonesia. Nature 2014, 514, 223-227.

[41] Nomade, S.; Genty, D.; Sasco, R.; Scao, V., et al. A 36,000-Year-Old Volcanic Eruption Depicted in the Chauvet-Pont d'Arc Cave (Ardèche, France)? PLOS ONE 2016, 11, e0146621. 
Biology and Philosophy. Part I. The Paleolithic.

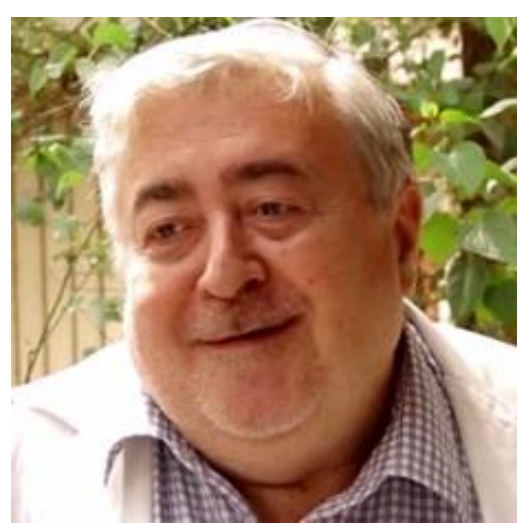

J.S. Gómez-Jeria. Graduate in Chemistry and Chemist at the University of Chile, PhD in Molecular Physical Chemistry (UNAB) Research in Quantitative Structure-Activity relationships, electronic structure of nanostructures and philosophy of science. Lecturer in Quantum Chemistry and Quantum Pharmacology, History and Philosophy of Science. In charge of Physical Chemistry teaching Labs. He has published three books and more than 150 papers. 